\title{
Simulation of Sediment Discharges during an Outfall Dredging Operation
}

\author{
Anton Purnama, ${ }^{1}$ Mahad S. Baawain, ${ }^{2}$ and Dongdong Shao ${ }^{3}$ \\ ${ }^{1}$ Department of Mathematics and Statistics, Sultan Qaboos University, P.O. Box 36, Al-Khod, 123 Muscat, Oman \\ ${ }^{2}$ Department of Civil and Architectural Engineering, Sultan Qaboos University, P.O. Box 33, Al-Khod, 123 Muscat, Oman \\ ${ }^{3}$ State Key Laboratory of Water Environment Simulation \& School of Environment, Beijing Normal University, Beijing 100875, China
}

Correspondence should be addressed to Anton Purnama; antonp@squ.edu.om

Received 31 October 2015; Accepted 31 December 2015

Academic Editor: Heinrich Hühnerfuss

Copyright (C) 2016 Anton Purnama et al. This is an open access article distributed under the Creative Commons Attribution License, which permits unrestricted use, distribution, and reproduction in any medium, provided the original work is properly cited.

CORMIX-GTS simulations are carried out to study suspended muddy sediment plumes following the discharge of the spoils taken from the seabed during a marine outfall pipeline dredging operation. Single port discharges are considered at three different locations at $400 \mathrm{~m}, 800 \mathrm{~m}$, and $1200 \mathrm{~m}$ from the shoreline with water depths ranging from $3.5 \mathrm{~m}$ to $10.5 \mathrm{~m}$. For discharges in the shallow near-shore region at $400 \mathrm{~m}$ offshore, most of the dredge materials are deposited at the seabed and the simulated suspended sediment plumes are found to be carrying a concentration of less than $1 \mathrm{~kg} / \mathrm{m}^{3}$ of mainly fine silt and clay. For discharges in the deeper far-shore region at $1200 \mathrm{~m}$ offshore, the sediment plumes are more elongated and carrying a concentration of more than $3 \mathrm{~kg} / \mathrm{m}^{3}$. Iterative simulations are also conducted to analyse the inherent uncertainty in the input data by varying the ambient velocity and the port's horizontal angle of discharge.

\section{Introduction}

For coastal capital cities, the practical strategy of wastewater disposal through an effective marine outfall is an affordable, effective, and reliable solution that is simple to operate and with minimal health and environmental impacts [1]. Modern wastewater treatment plants build a sufficiently long outfall pipeline for continuous discharges of treated wastewaters into the open sea. Underwater seabed excavation is therefore needed to establish a channel for laying and burying a submerged outfall pipeline, where the unwanted dredged material is disposed of at sea. The bar channel's length could be more than $1 \mathrm{~km}$ offshore, and the diameter of the pipe to be buried in the channel could be as large as up to $1.5 \mathrm{~m}$.

In the shallow near-shore region, less than $400 \mathrm{~m}$ from the shoreline, a mechanical dredger is usually used to remove the soil by scooping it with buckets from the seabed and placing it onto a waiting flat barge. Once the barge is full, it will transport the collected materials to a designated disposal site, where the dredged (suspended) sediment is discharged from the bottom of the barge. With the usage of two or more disposal barges, dredging operations can proceed continuously, only interrupted by changing barges or moving the dredger. However, since these mechanical dredgers are mounted on a large barge and are towed to the dredging site, they are not well suited for areas of rough seas. Therefore, in the far offshore region more than $400 \mathrm{~m}$ away from the shore, the side-casting disposal of dredged sediment is adopted, where the dredged materials taken from the seabed are directly discharged overboard to the side through an elevated discharge pipe into the sea surface.

The main environmental concerns for the underwater channel excavation and discharging dredged materials in coastal waters are associated with suspended sediments and increases in turbidity, which may result in an extended reduction in light penetration into the water column [27]. In general, however, these effects are short term and confined to the near field. Turbidity represents a complex composite of several variables that collectively influence the transparency of water. Frequently, as it may also contain plankton and microorganisms, it is poorly correlated with measurements of suspended solids [8]. The environmental 
effects of dredging are mainly dependent on where the spoil is deposited, and since temporarily suspended sediment plumes are mixed and dispersed by tidal currents, one of the purposes of the discharges is to make sure that dredged sediments are not deposited back to the bar channel. The particle size of sediments is of importance in understanding their likely impact in coastal waters. For example, sand particles settle quickly (the fall velocity of sand is about $31 \mathrm{~mm} / \mathrm{s}$ compared to that of fine silt being $0.026 \mathrm{~mm} / \mathrm{s}$ ) and are unlikely to move from the disposal site unless subject to extremely strong currents. Muddy sediment (up to fine silt size) in turbidity plumes is expected to settle more slowly, and this dredged particle could remain in suspension and be carried for more than $20 \mathrm{~km}$ downstream of the discharge point $[2,4,6,7]$.

The aim of this paper is to study the dispersion of dredged plume discharges during the seabed dredging work for laying and burying sea outfall pipelines. CORMIX-GTS (v9.0) simulations are carried out to assess the impact of dredginginduced turbidity plumes on the marine environment. The first simulation sets correspond to side-casting (near-shore) discharges at $400 \mathrm{~m}$ offshore with a shallow water depth of $3.5 \mathrm{~m}$, the second sets correspond to (midshore) discharges at $800 \mathrm{~m}$ offshore with a water depth of $7.0 \mathrm{~m}$, and the third sets correspond to (far-shore) discharges at $1200 \mathrm{~m}$ with a deeper water depth of $10.5 \mathrm{~m}$, where the dredged sediments are released through a single port at $1 \mathrm{~m}$ above the sea surface.

\section{CORMIX Mixing Zone Model}

The CORMIX modelling package (http://www.cormix.info/) is a software system for the analysis, prediction, and design of marine outfall mixing zones resulting from a continuous point discharge of effluents into open coastal waters [9]. It employs an easy-to-use rule-based expert system to screen input data and check for consistency and selects the appropriate hydrodynamic model to simulate the physical mixing processes likely to be present for many complex flow patterns within a given discharge-environment interaction (e.g., see Figure 1). Efficient computational algorithms provide simulation results in seconds for mixing zone problems with spatial scales of meters to kilometers. Extensive comparison with available field and laboratory data has shown that the CORMIX system predictions on plume concentrations (with associated plume geometries) are reliable for the majority of cases $[10,11]$.

The hydrodynamic flow classification schemes in the CORMIX system are developed based on dimensional analysis arguments as the detailed methods for modelling the dynamics of effluent discharges in complex physical situations are not available. Using the user input parameters, CORMIX classifies the flow class of the effluent discharge in the receiving water body based on the relative magnitudes of length scales (e.g., see Figure 1). These length scales, which measure the influence of each potential mixing process due to momentum flux and buoyancy of the discharge in relation to boundary interactions, are then used to predict steadystate mixing zone characteristics and plume dynamics such as free jets, shoreline-attached jets, wall jets, and upstream intruding plumes $[9,10]$. The model system has the ability to capture the key stages of effluent plume evolution: (i) in the near field region, where jet/plume dynamics are dominated by the momentum of the discharge; (ii) in the buoyant spreading region, where the buoyancy of the effluent stream is dynamically important; and (iii) in the ambient spreading region, where full vertical mixing has occurred and the effluent plume is controlled by the ambient flow.

CORMIX-GTS has advanced tools for suspended sediment (dredge sediments option) that extends the capability of CORMIX to simulate the initial mixing and dispersion of dredge sediment discharge, which includes side-casting surface discharge of sediments [11], and the (hydrodynamic module) DHYDRO simulates dense suspended sediment discharges (submerged, surface, and above surface) from a single port. CORMIX-GTS was developed in part through cooperation with the US EPA, the US Army Corps of Engineers, and the US Bureau of Reclamation [12].

The model includes the Stokes effect of particle settling on plume behaviour, with emphasis on the resulting plume density current, and accounts for the settling of five particle size classes, when using the default dredge sediments option $[9,11]$ : chunks: large, nonsuspended solids and stones which will separate out immediately from the plume; sand: suspended particles with settling velocity $0.031 \mathrm{~m} / \mathrm{s}$; coarse silt: suspended particles with settling velocity $0.42 \times 10^{-3} \mathrm{~m} / \mathrm{s}$; fine silt: suspended particles with settling velocity $0.26 \times 10^{-4} \mathrm{~m} / \mathrm{s}$; and clay: suspended particles with settling velocity $0.65 \times$ $10^{-6} \mathrm{~m} / \mathrm{s}$. For the shallow water depth of $3.5 \mathrm{~m}$, the settling time for sand particles is about 2 minutes, for coarse silt about 2.3 hours, for fine silt about 1.6 days, and for clay particle more than 62 days.

\section{Near-Shore Discharges at $400 \mathrm{~m}$ from the Shoreline}

The input data for the (above surface) side-casting discharge of dredge sediments at a distance of $400 \mathrm{~m}$ from the shoreline are summarized in Table 1, where the dredged sediments with a (total) concentration of $200 \mathrm{~kg} / \mathrm{m}^{3}$ (set as $100 \%$ ) are discharged overboard of the barge through an elevated $\left(45^{\circ}\right.$ inclined) pipe at $1 \mathrm{~m}$ above the sea surface to an unbounded, uniform sloping bed coastal environment. According to the particle sizes, this initial dredge sediment discharge consists of sand $20 \mathrm{~kg} / \mathrm{m}^{3}$, coarse silt $40 \mathrm{~kg} / \mathrm{m}^{3}$, fine silt $60 \mathrm{~kg} / \mathrm{m}^{3}$, and clay $80 \mathrm{~kg} / \mathrm{m}^{3}$. For the impact assessment study of effluent discharges in the marine environment, the region of interests would be a circular distance up to $500 \mathrm{~m}$ around the outfall discharge, and thus the CORMIX-GTS base simulation will be terminated at $1000 \mathrm{~m}$ downstream (in the ambient flow direction, $x$-axis). The ambient density is calculated at a temperature of $30^{\circ} \mathrm{C}$ (with a seawater salinity of $38 \mathrm{ppt}$ ), and similarly, using total sediment concentration of $200 \mathrm{~kg} / \mathrm{m}^{3}$, CORMIX calculates the effluent sediment density to be $1146.7 \mathrm{~kg} / \mathrm{m}^{3}$. Since the effluent density is greater than the surrounding water density $1023.98 \mathrm{~kg} / \mathrm{m}^{3}$, the resuspended 


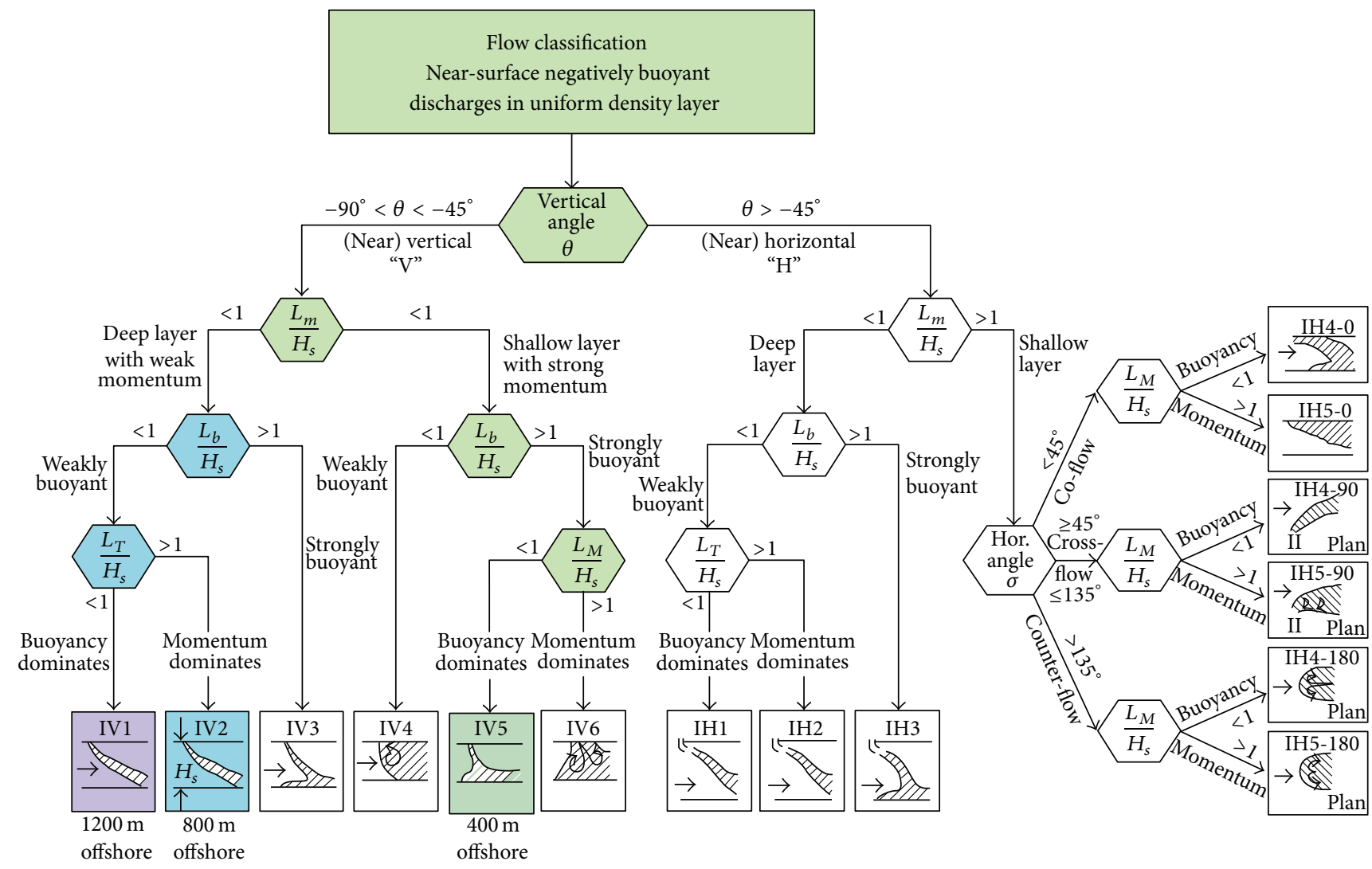

FIGURE 1: CORMIX flow classification for single port discharge in a uniform density layer [9].

TABLE 1: Input data for the CORMIX-GTS base simulations of dredge sediment discharges.

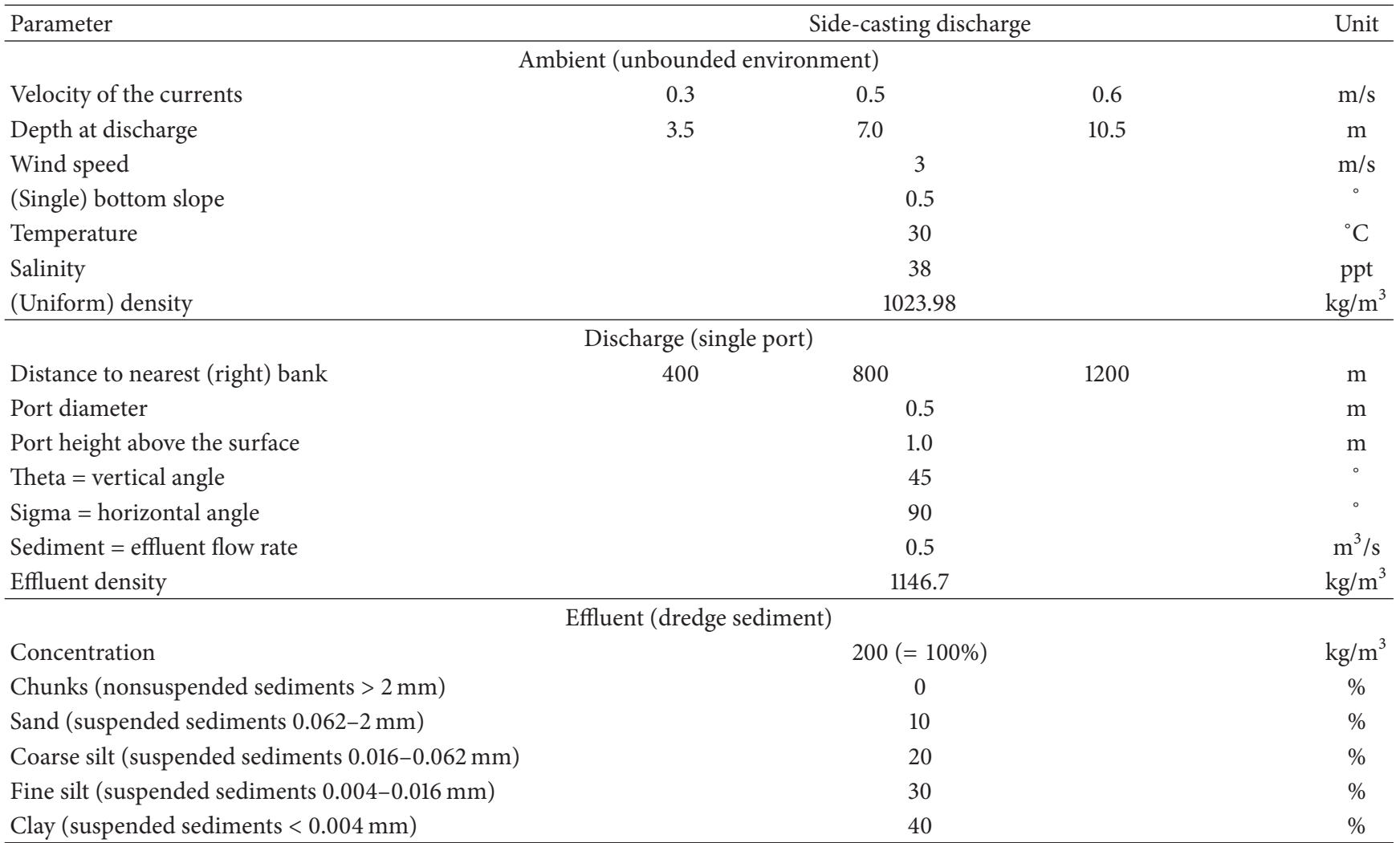




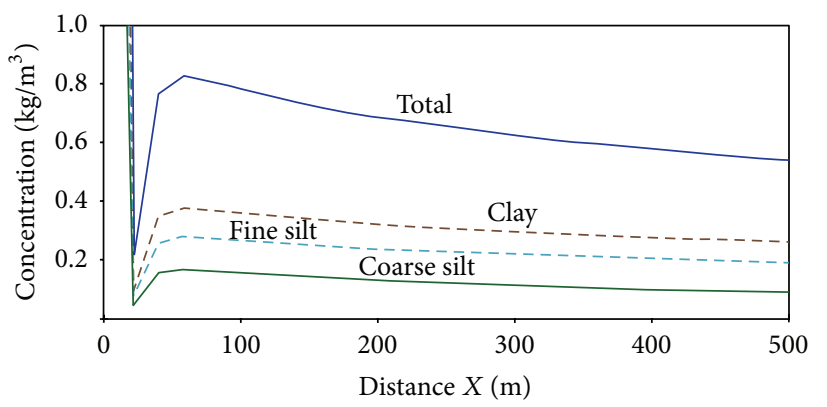

(a)

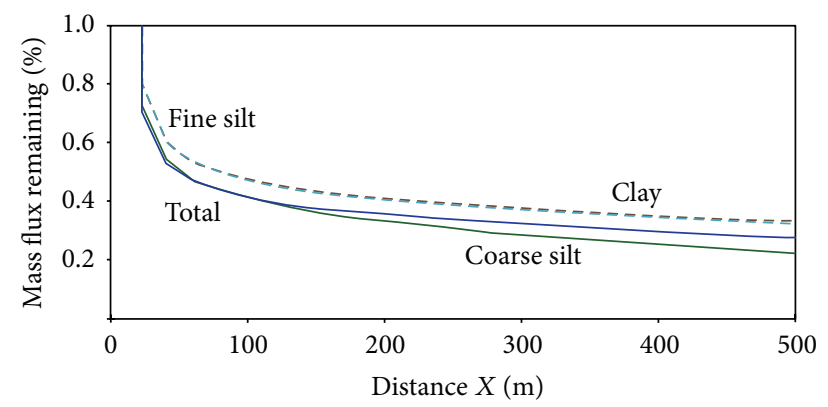

(b)

FIGURE 2: CORMIX-GTS simulations of near-shore discharges of dredge sediment at $400 \mathrm{~m}$ from the shoreline: (a) suspended sediment distribution (in the ambient flow direction) up to $500 \mathrm{~m}$ downstream from the discharge position and (b) sediment concentration (in \%) remaining in the suspension.

sediment (dense) plume is negatively buoyant and eventually sinks at the seabed.

To account for any lateral displacement from the discharge pipe to the point of entry at the water surface, CORMIX recomputed an additional distance travelled by the effluent discharge as $1.21 \mathrm{~m}$ with a vertical angle at entry $-69^{\circ}$. The new discharge position is thus set at $401.21 \mathrm{~m}$ from the shoreline. CORMIX classifies this kind of sediment flow as the flow class IV5 [9], a (surface) negatively buoyant flow in a (shallow) uniform density layer corresponding to the water depth $3.51 \mathrm{~m}$. This discharge configuration is claimed to be hydrodynamically stable, and as the initial jet-like discharge is weakly deflected by the ambient current into the flow direction, but due to the strong discharge buoyancy, the slightly bent over plume rapidly sinks to the sloping bed and impinges on the seabed within $21.84 \mathrm{~m}$ downstream (below the entry point). Impingement is a complex three-dimensional process, with more or less radial spreading, where the sediment accumulation of bottom deposit is formed [11]. Thereafter, as the suspended muddy plume loses its buoyancy by particle deposition at seabed, the plume continues to spread laterally as a bottom density current at the seabed while it is being advected by the ambient current, resulting in thinning of the plume and increased nonlinear lateral spreading.

After the sediment deposition at seabed, the muddy plume starts to resuspend with an initial mass flux remaining of $0.72 \%$ carrying a total suspended concentration of $0.22 \mathrm{~kg} / \mathrm{m}^{3}$, which mainly consists of coarse silt $0.05 \mathrm{~kg} / \mathrm{m}^{3}$, fine silt $0.07 \mathrm{~kg} / \mathrm{m}^{3}$, and clay $0.10 \mathrm{~kg} / \mathrm{m}^{3}$. As shown in Figure 2, the total suspended concentration is increased in a short distance, reaches a maximum value of $0.83 \mathrm{~kg} / \mathrm{m}^{3}$, and then disperses downstream. The dominant particle sizes in the suspended plume are clay, fine silt, and coarse silt, as represented in CORMIX-GTS by the sediment mass flux remaining, and, at the end of simulation (1000 $\mathrm{m}$ downstream), there is clay with more than $0.27 \%$, fine silt with $0.26 \%$, and coarse silt with $0.13 \%$.

The (total) concentration contours of the simulated suspended sediment plume are shown in Figure 3 at $100 \mathrm{~m}$ intervals. The total concentration is steadily reducing (after loss of suspended particles by settling) from $0.79 \mathrm{~kg} / \mathrm{m}^{3}$ at

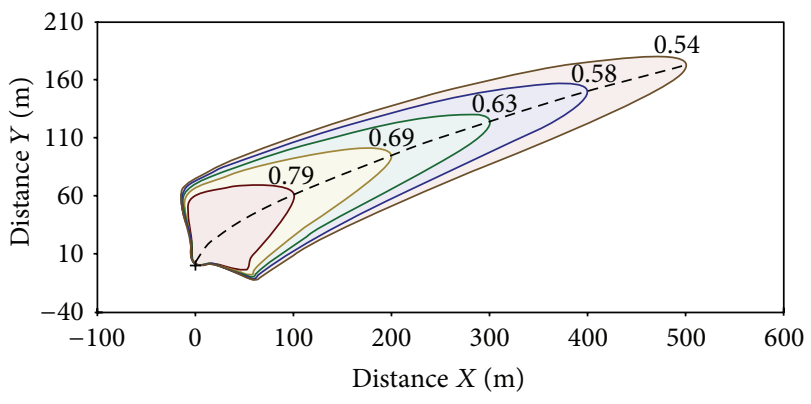

FIgURE 3: Contours of the suspended sediment concentration (in $\mathrm{kg} / \mathrm{m}^{3}$ ) as simulated by CORMIX-GTS following discharge at $400 \mathrm{~m}$ offshore.

$100 \mathrm{~m}$ to $0.54 \mathrm{~kg} / \mathrm{m}^{3}$ at $500 \mathrm{~m}$ downstream, and eventually it reaches a value of $0.42 \mathrm{~kg} / \mathrm{m}^{3}$ at $1000 \mathrm{~m}$ downstream (end of simulation). The lateral spreading of the contour centerline at $100 \mathrm{~m}$ is $61 \mathrm{~m}$, and it is increased to $174 \mathrm{~m}$ at $500 \mathrm{~m}$ downstream.

A sensitivity analysis is carried out to address CORMIX model performance due to inherent uncertainty in the input data [13]. First, to investigate the uncertainty in sea conditions, iterative simulations were carried out by varying the ambient velocity, while holding the other input parameters the same as the base simulation given in Table 1 . The CORMIX-GTS simulation results for increasing the ambient velocity values from 0.2 to $0.7 \mathrm{~m} / \mathrm{s}$ are presented in Table 2 , where there is flow class change from IV 5 to IV4 for velocities larger than $0.6 \mathrm{~m} / \mathrm{s}$. As the velocity values are reduced from $0.55 \mathrm{~m} / \mathrm{s}$, the size of bed deposition region increases and there are less particles resuspended. The flow class IV4 is classified as hydrodynamically unstable in CORMIX system $[9,11]$, as the momentum flux dominates and there is weak buoyancy of the discharge. The flow becomes unstable after impingement and forms a recirculating region immediately downstream over the full (shallow) water depth. The simulation results for flow class IV4 show overall higher sediment concentrations than that of class IV5.

The end of the (total) sediment concentration sharp drop (due to the initial seabed impingement) as shown in Figure 2 
TABLE 2: Summary of CORMIX-GTS iterative simulations results on varying the ambient velocity for discharges at $400 \mathrm{~m}$ offshore.

\begin{tabular}{lcccccccccc}
\hline $\begin{array}{l}\text { Ambient } \\
\text { velocity } \\
(\mathrm{m} / \mathrm{s})\end{array}$ & Flow class & $\begin{array}{c}\text { At } \\
(\mathrm{m})\end{array}$ & $\begin{array}{c}\text { Total } \\
\left(\mathrm{kg} / \mathrm{m}^{3}\right)\end{array}$ & $\begin{array}{c}\text { Clay } \\
\left(\mathrm{kg} / \mathrm{m}^{3}\right)\end{array}$ & $\begin{array}{c}\text { Total } \\
\left(\mathrm{kg} / \mathrm{m}^{3}\right)\end{array}$ & $\begin{array}{c}\text { Clay } \\
\left(\mathrm{kg} / \mathrm{m}^{3}\right)\end{array}$ & $\begin{array}{c}\text { Total } \\
\left(\mathrm{kg} / \mathrm{m}^{3}\right)\end{array}$ & $\begin{array}{c}\text { Clay } \\
\left(\mathrm{kg} / \mathrm{m}^{3}\right)\end{array}$ & $\begin{array}{c}\text { Total } \\
\left(\mathrm{kg} / \mathrm{m}^{3}\right)\end{array}$ & $\begin{array}{c}\text { Clay } \\
\left(\mathrm{kg} / \mathrm{m}^{3}\right)\end{array}$ \\
\hline 0.2 & IV5 & 24.95 & 0.06 & 0.03 & 0.37 & 0.18 & 0.28 & 0.14 & 0.23 & 0.13 \\
0.25 & IV5 & 23.03 & 0.13 & 0.06 & 0.56 & 0.26 & 0.41 & 0.20 & 0.33 & 0.17 \\
0.3 & IV5 & 21.84 & 0.22 & 0.10 & 0.79 & 0.36 & 0.54 & 0.26 & 0.42 & 0.21 \\
0.35 & IV5 & 21.02 & 0.36 & 0.16 & 1.07 & 0.49 & 0.68 & 0.33 & 0.50 & 0.25 \\
0.4 & IV5 & 20.46 & 0.61 & 0.27 & 1.44 & 0.65 & 0.82 & 0.39 & 0.58 & 0.29 \\
0.45 & IV5 & 19.97 & 1.06 & 0.46 & 1.94 & 0.87 & 0.98 & 0.47 & 0.67 & 0.33 \\
0.5 & IV5 & 19.54 & 2.01 & 0.85 & 2.69 & 1.20 & 1.24 & 0.59 & 0.81 & 0.41 \\
0.55 & IV5 & 19.58 & 3.30 & 1.38 & 4.25 & 1.91 & 1.85 & 0.89 & 1.18 & 0.61 \\
0.6 & IV4 & 22.91 & 14.11 & 6.06 & 12.68 & 5.79 & 5.35 & 2.76 & 3.34 & 1.90 \\
0.65 & IV4 & 23.30 & 14.83 & 6.36 & 13.26 & 6.06 & 5.59 & 2.88 & 3.49 & 1.97 \\
0.7 & IV4 & 23.60 & 15.40 & 6.59 & 13.82 & 6.31 & 5.83 & 3.00 & 3.64 & 2.05 \\
\hline
\end{tabular}

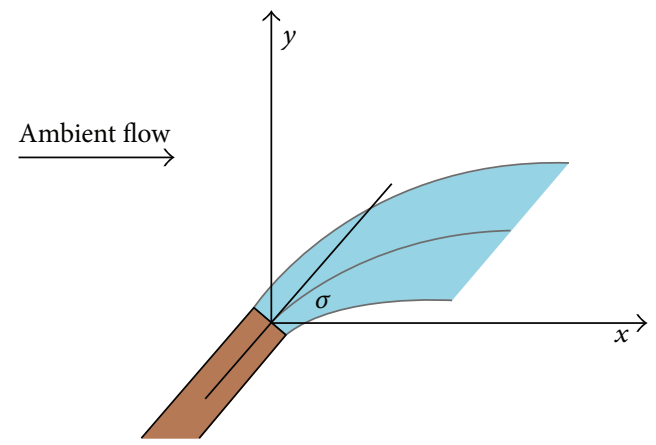

FIGURE 4: Diagram of the horizontal angle of discharge.

is referred to as the initial resuspension of sediment (in Table 2), and the subsequent suspended sediment concentrations are also reported at $100 \mathrm{~m}$ and $500 \mathrm{~m}$ downstream and finally at the end of CORMIX-GTS simulation at $1000 \mathrm{~m}$ downstream.

Next, the iterative CORMIX-GTS simulations were carried out to investigate the uncertainty in single port position by varying the horizontal angle of discharge $\sigma$ from 0 to $135^{\circ}$, while holding the other input parameters the same as the base simulation given in Table 1 (and CORMIX system reports unstable configuration for angles bigger than $135^{\circ}$ ) [9]. As sketched in Figure 4, the port's horizontal angle of discharge is defined as the angle measured counterclockwise from the direction of ambient velocity ( $x$-axis) to the plan projection of the port (centerline), and thus, a coflow discharge (in the ambient flow direction) refers to the port position when $\sigma=$ $0^{\circ}$, a cross-flow discharge (in the direction perpendicular to the ambient flow) when $\sigma=90^{\circ}$, and a counterflow discharge when $\sigma=180^{\circ}$. Ideally, a counterflow discharge in the opposite direction of the ambient current velocity should be avoided.

The CORMIX-GTS simulation results for increasing the horizontal angle of discharge values from 0 to $135^{\circ}$ are presented in Table 3, where there are no changes in the flow class IV5 reported. For this shallow water depth, CORMIX extends the specification of the counterflow discharges from $\sigma=120^{\circ}$, and thus the CORMIX (steady-state) results for both $\sigma=120^{\circ}$ and $\sigma=135^{\circ}$ are unrealistic and should be ignored. Similarly, CORMIX also specifies the coflow discharges for $\sigma \leq 30^{\circ}$, and the prediction is that muddy suspended plumes are more elongated (in the ambient flow direction) with less dispersion. It is suggested that CORMIX preferred horizontal angle of discharge is between $30^{\circ}$ and $105^{\circ}$.

\section{Midshore Discharges at $800 \mathrm{~m}$ from the Shoreline}

The input data for the CORMIX-GTS base simulation for the side-casting dredge sediment discharge through an elevated $\left(45^{\circ}\right.$ inclined) pipe at $1 \mathrm{~m}$ above the sea surface at a distance of $800 \mathrm{~m}$ from the shoreline are summarized in Table 1. Similar to the previous discharge of sediment at $400 \mathrm{~m}$ offshore, CORMIX recomputed the discharge conditions at entry point at the water surface to account for any lateral displacement and sets a new discharge position at $801.21 \mathrm{~m}$ from the shoreline with a vertical discharge angle $-69^{\circ}$. The sediment flow is classified as the flow class IV2, a (surface) negatively buoyant flow in a (deep) uniform density layer corresponding to the water depth $7.01 \mathrm{~m}$ [9]. The initial jet-like discharge in weak cross-flow is deflected by the ambient current and slowly sinks to the sloping bed. Deposition of sediments is occurring on the seabed within $23.79 \mathrm{~m}$ downstream (below the entry point), and, thereafter, as the suspended plume loses its buoyancy by particle settling, the muddy plume continues to spread laterally as a bottom density current at the seabed while it is being advected by the ambient current.

After sedimentation at the seabed (mainly due to the initial mass of larger sediment particles settling), the plume starts to resuspend with an initial mass flux remaining of $4.87 \%$ carrying a total suspended concentration of $7.64 \mathrm{~kg} / \mathrm{m}^{3}$, which mainly consists of sand $0.33 \mathrm{~kg} / \mathrm{m}^{3}$, coarse silt $1.61 \mathrm{~kg} / \mathrm{m}^{3}$, fine silt $2.44 \mathrm{~kg} / \mathrm{m}^{3}$, and clay $3.26 \mathrm{~kg} / \mathrm{m}^{3}$. As 
TABLE 3: Summary of CORMIX-GTS iterative simulations results on varying the horizontal angle of discharge for discharges at $400 \mathrm{~m}$ offshore.

\begin{tabular}{|c|c|c|c|c|c|c|c|c|c|c|}
\hline \multirow{2}{*}{$\begin{array}{l}\text { Sigma } \\
\text { (degrees) }\end{array}$} & \multirow{2}{*}{ Flow class } & \multicolumn{3}{|c|}{ Initial resuspension } & \multicolumn{2}{|c|}{$100 \mathrm{~m}$} & \multicolumn{2}{|c|}{$500 \mathrm{~m}$} & \multicolumn{2}{|c|}{$1000 \mathrm{~m}$} \\
\hline & & $\begin{array}{l}\text { at } \\
(\mathrm{m})\end{array}$ & $\begin{array}{c}\text { Total } \\
\left(\mathrm{kg} / \mathrm{m}^{3}\right)\end{array}$ & $\begin{array}{c}\text { Clay } \\
\left(\mathrm{kg} / \mathrm{m}^{3}\right)\end{array}$ & $\begin{array}{c}\text { Total } \\
\left(\mathrm{kg} / \mathrm{m}^{3}\right)\end{array}$ & $\begin{array}{c}\text { Clay } \\
\left(\mathrm{kg} / \mathrm{m}^{3}\right)\end{array}$ & $\begin{array}{c}\text { Total } \\
\left(\mathrm{kg} / \mathrm{m}^{3}\right)\end{array}$ & $\begin{array}{c}\text { Clay } \\
\left(\mathrm{kg} / \mathrm{m}^{3}\right)\end{array}$ & $\begin{array}{c}\text { Total } \\
\left(\mathrm{kg} / \mathrm{m}^{3}\right)\end{array}$ & $\begin{array}{c}\text { Clay } \\
\left(\mathrm{kg} / \mathrm{m}^{3}\right)\end{array}$ \\
\hline 0 & IV5 & 22.12 & 3.76 & 1.58 & 4.12 & 1.86 & 1.70 & 0.84 & 1.07 & 0.58 \\
\hline 15 & IV5 & 21.91 & 3.61 & 1.52 & 4.11 & 1.86 & 1.71 & 0.85 & 1.07 & 0.58 \\
\hline 30 & IV5 & 21.27 & 3.46 & 1.45 & 4.13 & 1.86 & 1.73 & 0.86 & 1.09 & 0.59 \\
\hline 45 & IV5 & 30.99 & 0.23 & 0.11 & 0.67 & 0.31 & 0.42 & 0.20 & 0.32 & 0.16 \\
\hline 60 & IV5 & 29.24 & 0.23 & 0.10 & 0.70 & 0.31 & 0.45 & 0.21 & 0.34 & 0.17 \\
\hline 75 & IV5 & 26.25 & 0.22 & 0.10 & 0.72 & 0.33 & 0.49 & 0.23 & 0.37 & 0.19 \\
\hline 90 & IV5 & 21.84 & 0.22 & 0.10 & 0.79 & 0.36 & 0.54 & 0.26 & 0.42 & 0.21 \\
\hline 105 & IV5 & 15.94 & 0.22 & 0.10 & 0.87 & 0.41 & 0.63 & 0.31 & 0.50 & 0.26 \\
\hline 120 & IV5 & 9.40 & 0.21 & 0.09 & 0.74 & 0.34 & 0.35 & 0.17 & 0.21 & 0.11 \\
\hline 135 & IV5 & 8.98 & 0.21 & 0.09 & 0.70 & 0.32 & 0.37 & 0.18 & 0.23 & 0.12 \\
\hline
\end{tabular}

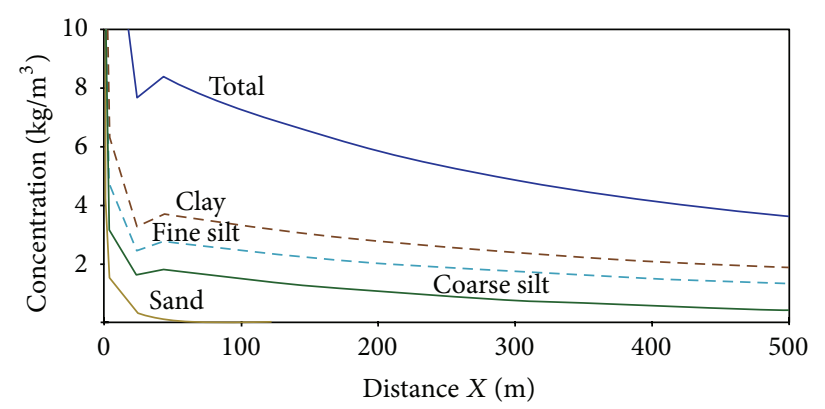

(a)

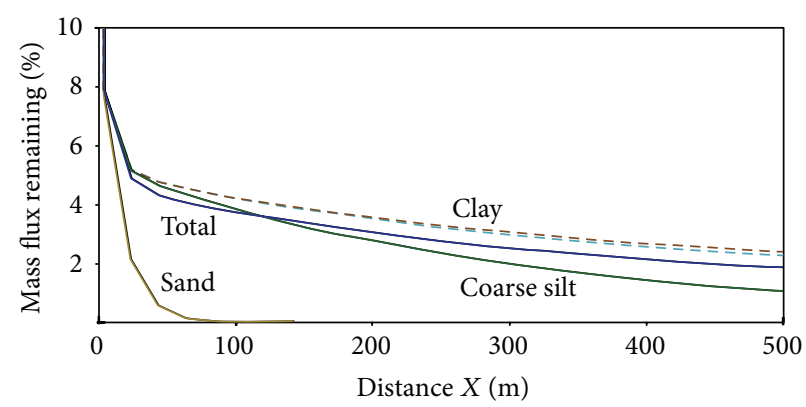

(b)

FIGURE 5: CORMIX-GTS simulations of midshore discharges of dredge sediment at $800 \mathrm{~m}$ from the shoreline: (a) suspended sediment distribution (in the ambient flow direction) up to $500 \mathrm{~m}$ downstream from the discharge position and (b) sediment concentration (in \%) remaining in suspension.

shown in Figure 5, the total suspended concentration jumped immediately to reach a maximum value of $8.40 \mathrm{~kg} / \mathrm{m}^{3}$ and then disperses downstream. Within $500 \mathrm{~m}$ downstream, the dominant particle sizes in the suspended plume are clay, fine silt, and coarse silt, as represented in CORMIX-GTS by the sediment mass flux remaining. The first particle size to settle out completely from the plume is sand within $83 \mathrm{~m}$ downstream, and, at the end of simulation $(1000 \mathrm{~m}$ downstream), there is clay with more than $1.65 \%$, fine silt with $1.48 \%$, and coarse silt with $0.27 \%$.

The (total) concentration contours of the simulated suspended sediment plume are shown in Figure 6 at $100 \mathrm{~m}$ intervals. The total concentration is steadily reducing (after loss of suspended particles by settling) from $7.21 \mathrm{~kg} / \mathrm{m}^{3}$ at $100 \mathrm{~m}$ downstream to $3.61 \mathrm{~kg} / \mathrm{m}^{3}$ at $500 \mathrm{~m}$ and eventually reaches a value of $2.29 \mathrm{~kg} / \mathrm{m}^{3}$ at $1000 \mathrm{~m}$ downstream (end of simulation). The plume is elongated in the ambient flow direction with the lateral spread of contour centerline at $500 \mathrm{~m}$ to be slightly over $40 \mathrm{~m}$.

The CORMIX-GTS iterative simulation results of increasing the ambient velocity from 0.3 to $0.7 \mathrm{~m} / \mathrm{s}$ are presented in Table 4, where there is a flow class change from IV2 to IV3 and IV5 for velocities $0.45 \mathrm{~m} / \mathrm{s}$ and smaller than
$0.4 \mathrm{~m} / \mathrm{s}$, respectively. After the impingement, and due to a strong buoyancy, the flow class IV3 spreads at the seabed over some distance upstream against the ambient flow up to the intrusion length of $5.21 \mathrm{~m}$. For weaker ambient currents, the upstream intrusion length of the flow class IV5 is getting longer, and it reaches $10.30 \mathrm{~m}$ for the ambient velocity $0.3 \mathrm{~m} / \mathrm{s}$. The simulation results show overall higher sediment concentrations than that of flow class IV2 with stronger currents greater than $0.5 \mathrm{~m} / \mathrm{s}$.

The iterative simulation results on varying the horizontal angle of discharge from 0 to $135^{\circ}$ are presented in Table 5, where there are no changes in the flow class IV 2 reported. It is found that, similar to the previous near-shore discharges, the CORMIX preferred horizontal angle of discharge is between $30^{\circ}$ and $90^{\circ}$ and will produce a smaller suspended sediment concentration.

\section{Far-Shore Discharges at $1200 \mathrm{~m}$ from the Shoreline}

Input data for the side-casting discharge of dredge sediment through an elevated $\left(45^{\circ}\right.$ inclined) pipe at $1 \mathrm{~m}$ above the sea surface at a distance of $1200 \mathrm{~m}$ from the shoreline are summarized in Table 1. Again, CORMIX-GTS recomputed 
TABLE 4: Summary of CORMIX-GTS iterative simulations results on varying the ambient velocity for discharges at $800 \mathrm{~m}$ offshore.

\begin{tabular}{lcccccccccc}
\hline $\begin{array}{l}\text { Ambient } \\
\text { velocity } \\
(\mathrm{m} / \mathrm{s})\end{array}$ & Flow class & $\begin{array}{c}\text { At } \\
(\mathrm{m})\end{array}$ & $\begin{array}{c}\text { Total } \\
\left(\mathrm{kg} / \mathrm{m}^{3}\right)\end{array}$ & $\begin{array}{c}\text { Clay } \\
\left(\mathrm{kg} / \mathrm{m}^{3}\right)\end{array}$ & $\begin{array}{c}\text { Total } \\
\left(\mathrm{kg} / \mathrm{m}^{3}\right)\end{array}$ & $\begin{array}{c}\text { Clay } \\
\left(\mathrm{kg} / \mathrm{m}^{3}\right)\end{array}$ & $\begin{array}{c}\text { Total } \\
\left(\mathrm{kg} / \mathrm{m}^{3}\right)\end{array}$ & $\begin{array}{c}\text { Clay } \\
\left(\mathrm{kg} / \mathrm{m}^{3}\right)\end{array}$ & $\begin{array}{c}\text { Total } \\
\left(\mathrm{kg} / \mathrm{m}^{3}\right)\end{array}$ & $\begin{array}{c}\text { Clay } \\
\left(\mathrm{kg} / \mathrm{m}^{3}\right)\end{array}$ \\
\hline 0.3 & IV5 & 26.12 & 11.89 & 5.42 & 9.13 & 4.45 & 4.85 & 2.92 & 3.36 & 2.21 \\
0.35 & IV5 & 25.47 & 11.53 & 5.21 & 9.38 & 4.49 & 4.96 & 2.92 & 3.37 & 2.17 \\
0.4 & IV5 & 25.00 & 11.03 & 4.95 & 9.20 & 4.33 & 5.02 & 2.89 & 3.36 & 2.12 \\
0.45 & IV3 & 24.80 & 10.47 & 4.66 & 8.81 & 4.10 & 5.01 & 2.81 & 3.31 & 2.05 \\
0.5 & IV2 & 23.79 & 7.64 & 3.26 & 7.21 & 3.28 & 3.61 & 1.87 & 2.29 \\
0.55 & IV2 & 24.37 & 7.56 & 3.21 & 7.06 & 3.20 & 3.85 & 1.98 & 2.45 \\
0.6 & IV2 & 24.94 & 7.49 & 3.17 & 6.81 & 3.09 & 4.06 & 2.07 & 2.60 \\
0.65 & IV2 & 25.53 & 7.02 & 2.95 & 6.35 & 2.87 & 4.18 & 2.11 & 2.74 & 1.39 \\
0.7 & IV2 & 26.21 & 6.58 & 2.75 & 5.81 & 2.62 & 4.18 & 2.08 & 2.86 \\
0.75 & IV2 & 26.88 & 6.20 & 2.59 & 5.29 & 2.38 & 4.04 & 1.99 & 2.94 & 1.53 \\
0.8 & IV2 & 27.69 & 5.90 & 2.45 & 4.84 & 2.17 & 3.84 & 1.87 & 2.96 & 1.60 \\
\hline
\end{tabular}

TABLE 5: Summary of CORMIX-GTS iterative simulations results on varying the horizontal angle of discharge for discharges at $800 \mathrm{~m}$ offshore.

\begin{tabular}{|c|c|c|c|c|c|c|c|c|c|c|}
\hline \multirow{2}{*}{$\begin{array}{l}\text { Sigma } \\
\text { (degrees) }\end{array}$} & \multirow{2}{*}{ Flow class } & \multicolumn{3}{|c|}{ Initial resuspension } & \multicolumn{2}{|c|}{$100 \mathrm{~m}$} & \multicolumn{2}{|c|}{$500 \mathrm{~m}$} & \multicolumn{2}{|c|}{$1000 \mathrm{~m}$} \\
\hline & & $\begin{array}{l}\text { At } \\
(\mathrm{m})\end{array}$ & $\begin{array}{c}\text { Total } \\
\left(\mathrm{kg} / \mathrm{m}^{3}\right)\end{array}$ & $\begin{array}{c}\text { Clay } \\
\left(\mathrm{kg} / \mathrm{m}^{3}\right)\end{array}$ & $\begin{array}{c}\text { Total } \\
\left(\mathrm{kg} / \mathrm{m}^{3}\right)\end{array}$ & $\begin{array}{c}\text { Clay } \\
\left(\mathrm{kg} / \mathrm{m}^{3}\right)\end{array}$ & $\begin{array}{c}\text { Total } \\
\left(\mathrm{kg} / \mathrm{m}^{3}\right)\end{array}$ & $\begin{array}{c}\text { Clay } \\
\left(\mathrm{kg} / \mathrm{m}^{3}\right)\end{array}$ & $\begin{array}{c}\text { Total } \\
\left(\mathrm{kg} / \mathrm{m}^{3}\right)\end{array}$ & $\begin{array}{c}\text { Clay } \\
\left(\mathrm{kg} / \mathrm{m}^{3}\right)\end{array}$ \\
\hline 0 & IV2 & 26.15 & 9.10 & 3.88 & 7.05 & 3.21 & 3.34 & 1.71 & 2.10 & 1.19 \\
\hline 15 & IV2 & 26.04 & 8.58 & 3.65 & 6.93 & 3.15 & 3.34 & 1.71 & 2.11 & 1.19 \\
\hline 30 & IV2 & 25.83 & 8.16 & 3.47 & 6.84 & 3.11 & 3.36 & 1.72 & 2.12 & 1.20 \\
\hline 45 & IV2 & 25.49 & 7.84 & 3.34 & 6.81 & 3.09 & 3.39 & 1.74 & 2.14 & 1.21 \\
\hline 60 & IV2 & 25.03 & 7.65 & 3.26 & 6.85 & 3.12 & 3.44 & 1.77 & 2.18 & 1.23 \\
\hline 75 & IV2 & 24.46 & 7.58 & 3.23 & 6.48 & 3.18 & 3.51 & 1.81 & 2.23 & 1.26 \\
\hline 90 & IV2 & 23.79 & 7.64 & 3.26 & 7.21 & 3.28 & 3.61 & 1.87 & 2.29 & 1.30 \\
\hline 105 & IV2 & 23.12 & 7.82 & 3.34 & 7.51 & 3.42 & 3.72 & 1.93 & 2.36 & 1.35 \\
\hline 120 & IV2 & 22.56 & 8.15 & 3.49 & 7.82 & 3.56 & 3.81 & 1.99 & 2.41 & 1.39 \\
\hline 135 & IV2 & 22.15 & 8.71 & 3.74 & 8.14 & 3.71 & 3.87 & 2.02 & 2.44 & 1.41 \\
\hline
\end{tabular}

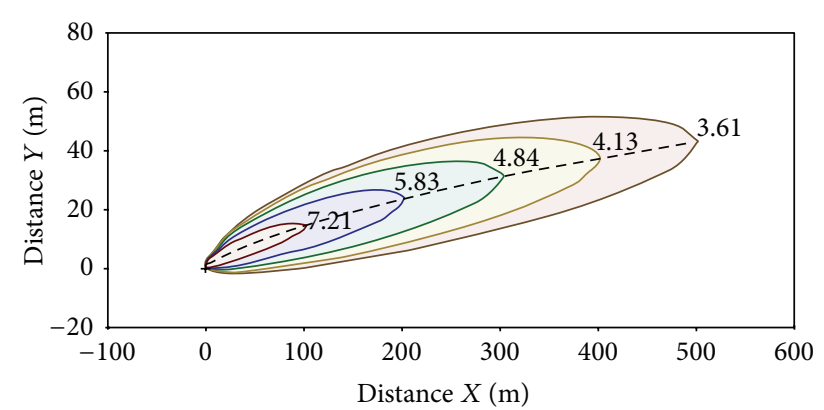

Figure 6: Contours of the suspended sediment concentration (in $\mathrm{kg} / \mathrm{m}^{3}$ ) as simulated by CORMIX-GTS following discharge at $800 \mathrm{~m}$ offshore.

the discharge conditions to account for any lateral displacement and set a new discharge position of $1201.21 \mathrm{~m}$ from the shoreline with a vertical discharge angle $-69^{\circ}$ at entry point at the water surface. The sediment flow is classified as the flow class IV1, a (surface) negatively buoyant flow in a (deep) uniform density layer corresponding to the water depth $10.51 \mathrm{~m}$ [4]. The initial jet/plume in strong cross-flow is strongly deflected by the ambient current and rapidly falls toward the sloping seabed within $30.38 \mathrm{~m}$ downstream, and the plume stays at the seabed due to its negative buoyancy with loss of suspended particles by sedimentation. Thereafter, the plume continues to travel downslope as a bottom density current at the seabed while it is being advected by the ambient current.

As shown in Figure 7, the suspended sediment plume disperses downstream with an initial mass flux remaining of $2.13 \%$ carrying a total suspended concentration of $4.09 \mathrm{~kg} / \mathrm{m}^{3}$, which mainly consists of sand $0.27 \mathrm{~kg} / \mathrm{m}^{3}$, coarse silt $0.84 \mathrm{~kg} / \mathrm{m}^{3}$, fine silt $1.27 \mathrm{~kg} / \mathrm{m}^{3}$, and clay $1.7 \mathrm{~kg} / \mathrm{m}^{3}$. Similar to the previous sediment discharge at $800 \mathrm{~m}$ offshore, the dominant particle sizes in the muddy suspended plume are, as represented in CORMIX-GTS by the sediment mass flux remaining, clay, fine silt, and coarse silt. The first particle size to settle out completely from the plume is sand within 


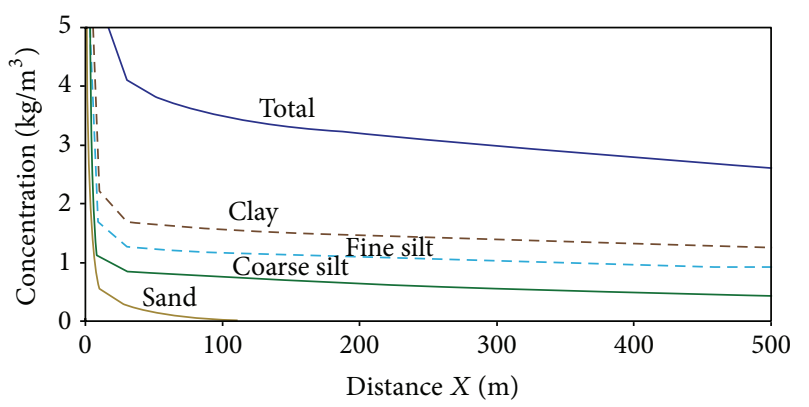

(a)

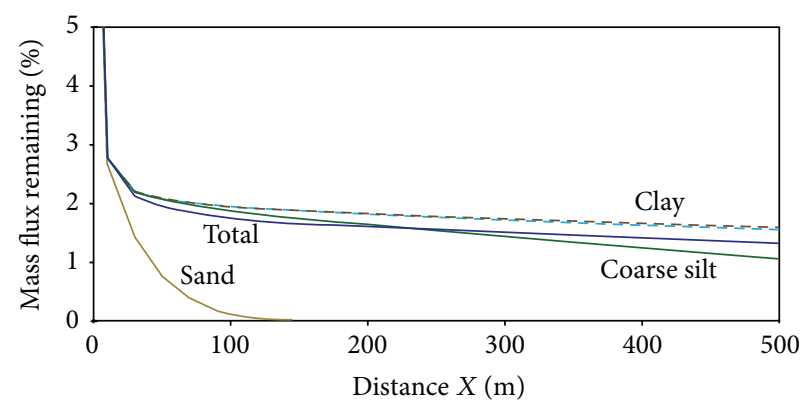

(b)

Figure 7: CORMIX-GTS simulations of far-shore discharges of dredge sediment at $1200 \mathrm{~m}$ from the shoreline: (a) suspended sediment distribution (in the ambient flow direction) up to $500 \mathrm{~m}$ downstream from the discharge position and (b) sediment concentration (in \%) remaining in the suspension.

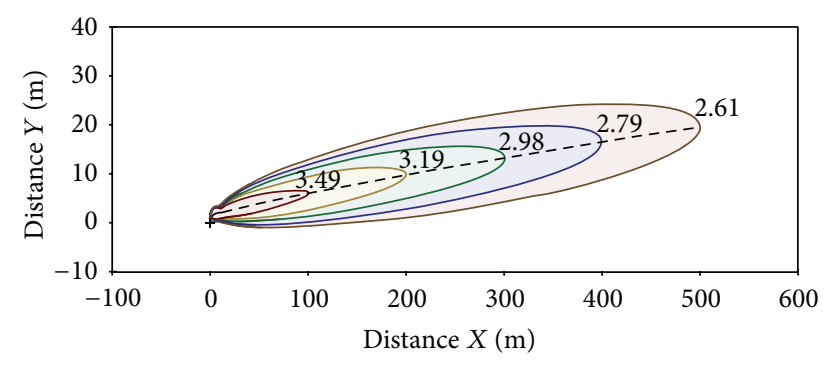

FIGURE 8: Contours of the suspended sediment concentration (in $\mathrm{kg} / \mathrm{m}^{3}$ ) as simulated by CORMIX-GTS following discharge at $1200 \mathrm{~m}$ offshore.

$150 \mathrm{~m}$ downstream and, at the end of simulation $(1000 \mathrm{~m}$ downstream), there is clay with more than $1.25 \%$, fine silt with $1.17 \%$, and coarse silt with $0.44 \%$.

The (total) concentration contours of the simulated suspended sediment plume are shown in Figure 8 at $100 \mathrm{~m}$ intervals. The total concentration is steadily reducing (after loss of suspended particles by settling) from $3.49 \mathrm{~kg} / \mathrm{m}^{3}$ at $100 \mathrm{~m}$ to $2.61 \mathrm{~kg} / \mathrm{m}^{3}$ at $500 \mathrm{~m}$ downstream and eventually reaches a value of $1.86 \mathrm{~kg} / \mathrm{m}^{3}$ at $1000 \mathrm{~m}$ downstream (end of simulation). The plume is more elongated in the flow direction with the lateral spread of the contour centerline at $500 \mathrm{~m}$ at slightly less than $20 \mathrm{~m}$, that is, half the width of the previous midshore discharges.

The CORMIX-GTS iterative simulation results of increasing the ambient velocity from 0.4 to $0.9 \mathrm{~m} / \mathrm{s}$ are presented in Table 6, where there is a flow class change from IV1 to IV3 for velocities smaller than $0.4 \mathrm{~m} / \mathrm{s}$. Due to strong buoyancy and weaker current, and, after the impingement, the flow class IV3 spreads at the seabed over some distance upstream against the ambient flow up to the intrusion length of $7.01 \mathrm{~m}$. As the current is increased from $0.45 \mathrm{~m} / \mathrm{s}$, the size of the bed deposition region increases and there are less sediments resuspended.

Next, the iterative CORMIX-GTS simulations were carried out by varying the position of discharge from 0 to $135^{\circ}$. The results are presented in Table 7 , where there are no changes in the flow class IV1 reported. Again, it is clear that, for the near coflow discharges for $\sigma \leq 30^{\circ}$, CORMIX predictions are only slightly different, and, however, the near counterflow discharges for $\sigma \geq 105^{\circ}$ should be avoided.

\section{Conclusion}

CORMIX-GTS simulations were run for three scenarios of side-casting (above surface) discharges of seabed dredge sediments during an outfall dredging operation at $400 \mathrm{~m}$, $800 \mathrm{~m}$, and $1200 \mathrm{~m}$ from the shoreline, where the initial dredged seabed spoil consists of sand $20 \mathrm{~kg} / \mathrm{m}^{3}$, coarse silt $40 \mathrm{~kg} / \mathrm{m}^{3}$, fine silt $60 \mathrm{~kg} / \mathrm{m}^{3}$, and clay $80 \mathrm{~kg} / \mathrm{m}^{3}$. The dredginginduced turbidity plumes with a concentration of more than 0.03 are visible from the surface.

CORMIX-GTS simulation results for discharges in the near shore (at $400 \mathrm{~m}$ from the shoreline) with a shallow water depth of $3.5 \mathrm{~m}$ show that most of the sediments are immediately deposited at the seabed due to the initial momentum and buoyancy of discharge, and the muddy turbidity plumes with a concentration of less than $1 \mathrm{~kg} / \mathrm{m}^{3}$ of mainly coarse silt, fine silt, and clay are remained in suspension for large distances more than $500 \mathrm{~m}$ downstream. For discharges in the far shore (at $1200 \mathrm{~m}$ from the shoreline) with a deeper water depth of $10.5 \mathrm{~m}$, the results show that bottom sedimentation is formed by sediments settling out, and the suspended sediment plumes are more elongated (in the ambient flow direction) and carrying a concentration of more than $3 \mathrm{~kg} / \mathrm{m}^{3}$ of coarse silt, fine silt, and clay. Therefore, if a suitable disposal site can be chosen from the regional bathymetry of the coastline to absorb the accumulation of bottom deposit, then discharges in the near shore are the preferred and best option.

CORMIX-GTS simulations also predict that, for the near coflow discharges with the horizontal angle of discharge $\sigma \leq 30^{\circ}$, the muddy suspended sediment plumes are more elongated with less dispersion. The near counterflow discharges for $\sigma \geq 105^{\circ}$ (i.e., in the opposite direction of the ambient velocity) should be avoided. It is suggested that the CORMIX preferred horizontal angle of discharge is between $30^{\circ}$ and $105^{\circ}$. 
TABLE 6: Summary of CORMIX-GTS iterative simulations results on varying the ambient velocity for discharges at $1200 \mathrm{~m}$ offshore.

\begin{tabular}{lcccccccccc}
\hline $\begin{array}{l}\text { Ambient } \\
\begin{array}{l}\text { velocity } \\
(\mathrm{m} / \mathrm{s})\end{array}\end{array}$ & Flow class & $\begin{array}{c}\text { At } \\
(\mathrm{m})\end{array}$ & $\begin{array}{c}\text { Total } \\
\left(\mathrm{kg} / \mathrm{m}^{3}\right)\end{array}$ & $\begin{array}{c}\text { Clay } \\
\left(\mathrm{kg} / \mathrm{m}^{3}\right)\end{array}$ & $\begin{array}{c}\text { Total } \\
\left(\mathrm{kg} / \mathrm{m}^{3}\right)\end{array}$ & $\begin{array}{c}\text { Clay } \\
\left(\mathrm{kg} / \mathrm{m}^{3}\right)\end{array}$ & $\begin{array}{c}\text { Total } \\
\left(\mathrm{kg} / \mathrm{m}^{3}\right)\end{array}$ & $\begin{array}{c}\text { Clay } \\
\left(\mathrm{kg} / \mathrm{m}^{3}\right)\end{array}$ & $\begin{array}{c}\text { Total } \\
\left(\mathrm{kg} / \mathrm{m}^{3}\right)\end{array}$ & $\begin{array}{c}\text { Clay } \\
\left(\mathrm{kg} / \mathrm{m}^{3}\right)\end{array}$ \\
\hline 0.4 & IV3 & 28.06 & 5.81 & 2.57 & 5.00 & 2.29 & 3.20 & 1.71 & 2.13 \\
0.45 & IV1 & 26.99 & 4.96 & 2.09 & 4.35 & 1.96 & 2.42 & 1.21 & 1.55 & 0.26 \\
0.5 & IV1 & 27.97 & 4.74 & 1.99 & 4.11 & 1.85 & 2.56 & 1.27 & 1.67 & 0.91 \\
0.55 & IV1 & 29.15 & 4.49 & 1.88 & 3.83 & 1.72 & 2.64 & 1.30 & 1.78 & 0.96 \\
0.6 & IV1 & 30.38 & 4.09 & 1.70 & 3.49 & 1.55 & 2.61 & 1.26 & 1.86 & 0.99 \\
0.65 & IV1 & 31.65 & 3.77 & 1.56 & 3.11 & 1.38 & 2.44 & 1.17 & 1.89 & 0.99 \\
0.7 & IV1 & 33.04 & 3.48 & 1.44 & 2.80 & 1.23 & 2.26 & 1.07 & 1.85 & 0.96 \\
0.75 & IV1 & 34.48 & 3.19 & 1.31 & 2.55 & 1.12 & 2.08 & 0.98 & 1.78 & 0.90 \\
0.8 & IV1 & 35.95 & 2.94 & 1.21 & 2.36 & 1.03 & 1.93 & 0.90 & 1.68 & 0.84 \\
0.85 & IV1 & 37.60 & 2.73 & 1.12 & 2.23 & 0.97 & 1.80 & 0.83 & 1.59 & 0.78 \\
0.9 & IV1 & 39.25 & 2.55 & 1.04 & 2.10 & 0.91 & 1.69 & 0.78 & 1.50 & 0.73 \\
\hline
\end{tabular}

TABLE 7: Summary of CORMIX-GTS iterative simulations results on varying the horizontal angle of discharge for discharges at $1200 \mathrm{~m}$ offshore.

\begin{tabular}{|c|c|c|c|c|c|c|c|c|c|c|}
\hline \multirow{2}{*}{$\begin{array}{l}\text { Sigma } \\
\text { (degrees) }\end{array}$} & \multirow{2}{*}{ Flow class } & \multicolumn{3}{|c|}{ Initial resuspension } & \multicolumn{2}{|c|}{$100 \mathrm{~m}$} & \multicolumn{2}{|c|}{$500 \mathrm{~m}$} & \multicolumn{2}{|c|}{$1000 \mathrm{~m}$} \\
\hline & & $\begin{array}{l}\text { At } \\
(\mathrm{m})\end{array}$ & $\begin{array}{c}\text { Total } \\
\left(\mathrm{kg} / \mathrm{m}^{3}\right)\end{array}$ & $\begin{array}{c}\text { Clay } \\
\left(\mathrm{kg} / \mathrm{m}^{3}\right)\end{array}$ & $\begin{array}{c}\text { Total } \\
\left(\mathrm{kg} / \mathrm{m}^{3}\right)\end{array}$ & $\begin{array}{c}\text { Clay } \\
\left(\mathrm{kg} / \mathrm{m}^{3}\right)\end{array}$ & $\begin{array}{c}\text { Total } \\
\left(\mathrm{kg} / \mathrm{m}^{3}\right)\end{array}$ & $\begin{array}{c}\text { Clay } \\
\left(\mathrm{kg} / \mathrm{m}^{3}\right)\end{array}$ & $\begin{array}{c}\text { Total } \\
\left(\mathrm{kg} / \mathrm{m}^{3}\right)\end{array}$ & $\begin{array}{c}\text { Clay } \\
\left(\mathrm{kg} / \mathrm{m}^{3}\right)\end{array}$ \\
\hline 0 & IV1 & 28.06 & 3.97 & 1.65 & 3.31 & 1.48 & 2.47 & 1.19 & 1.78 & 0.94 \\
\hline 15 & IV1 & 26.99 & 3.94 & 1.63 & 3.28 & 1.45 & 2.45 & 1.18 & 1.77 & 0.94 \\
\hline 30 & IV1 & 27.97 & 3.91 & 1.62 & 3.24 & 1.44 & 2.44 & 1.18 & 1.77 & 0.94 \\
\hline 45 & IV1 & 29.15 & 3.88 & 1.61 & 3.24 & 1.44 & 2.44 & 1.18 & 1.78 & 0.94 \\
\hline 60 & IV1 & 30.38 & 3.89 & 1.61 & 3.28 & 1.46 & 2.47 & 1.19 & 1.80 & 0.95 \\
\hline 75 & IV1 & 31.65 & 3.96 & 1.64 & 3.36 & 1.50 & 2.52 & 1.22 & 1.82 & 0.97 \\
\hline 90 & IV1 & 33.04 & 4.09 & 1.70 & 3.49 & 1.55 & 2.61 & 1.26 & 1.86 & 0.99 \\
\hline 105 & IV1 & 34.48 & 4.27 & 1.78 & 3.67 & 1.64 & 2.69 & 1.31 & 1.91 & 1.02 \\
\hline 120 & IV1 & 35.95 & 4.49 & 1.87 & 3.86 & 1.73 & 2.79 & 1.36 & 1.95 & 1.05 \\
\hline 135 & IV1 & 37.60 & 4.75 & 1.98 & 4.06 & 1.81 & 2.88 & 1.41 & 1.98 & 1.07 \\
\hline
\end{tabular}

One major inherent limitation in the CORMIX system is the representation of the coastal environment as a uniformly sloping cross section channel where the ambient velocity is assumed to be uniform. Another limitation is the flow classification based on hydrodynamic criteria using length scale analysis, where the subsequent simulation is carried out without detailed numerical analysis and computation. For example, as shown in Table 2, a slight variation in the input parameters may result in different flow classes. The steadystate sediment depositing density current on a sloping bed is used for the calculation, and the effect of ambient cross-flow is ignored.

\section{Conflict of Interests}

The authors declare that there is no conflict of interests regarding the publication of this paper.

\section{References}

[1] P. J. W. Roberts, H. J. Salas, F. M. Reiff, M. Libhaber, A. Labbe, and J. C. Thomson, Marine Wastewater Outfalls and Treatment Systems, IWA Publishing, Amsterdam, The Netherlands, 2010.

[2] C.-H. Je, D. F. Hayes, and K.-S. Kim, "Simulation of resuspended sediments resulting from dredging operations by a numerical flocculent transport model," Chemosphere, vol. 70, no. 2, pp. 187-195, 2007.

[3] D. D. Shao, A. Purnama, and T. Sun, "Modeling the temporal evolution of dredging-induced turbidity in the far field," Journal of Waterway, Port, Coastal, and Ocean Engineering, vol. 141, no. 5, Article ID 04015001, 2015.

[4] R. N. Bray, Environmental Aspects of Dredging, Taylor \& Francis, London, UK, 2008.

[5] A. Y. Kuo and D. F. Hayes, "Model for turbidity plume induced by bucket dredge," Journal of Waterway, Port, Coastal and Ocean Engineering, vol. 117, no. 6, pp. 610-623, 1991. 
[6] J. Roman-Sierra, M. Navarro, J. J. Muñoz-Perez, and G. GomezPina, "Turbidity and other effects resulting from Trafalgar sandbank dredging and Palmar beach nourishment," Journal of Waterway, Port, Coastal and Ocean Engineering, vol. 137, no. 6, pp. 332-343, 2011.

[7] G. F. Wu, J. de Leeuw, A. K. Skidmore, H. H. T. Prins, and Y. L. Liu, "Concurrent monitoring of vessels and water turbidity enhances the strength of evidence in remotely sensed dredging impact assessment," Water Research, vol. 41, no. 15, pp. 32713280, 2007.

[8] C. L. Truitt, "Dredged material behavior during open-water disposal," Journal of Coastal Research, vol. 4, no. 3, pp. 489-497, 1988.

[9] R. L. Doneker and G. H. Jirka, CORMIX User Manual: A Hydrodynamic Mixing Zone Model and Decision Support System for Pollutant Discharges Into Surface Waters, MixZon, Portland, Ore, USA, 2007, http://www.cormix.info.

[10] G. H. Jirka, "Integral model for turbulent buoyant jets in unbounded stratified flows. Part I: single round jet," Environmental Fluid Mechanics, vol. 4, no. 1, pp. 1-56, 2004.

[11] R. L. Doneker, J. D. Nash, and G. H. Jirka, "Pollutant transport and mixing zone simulation of sediment density currents," Journal of Hydraulic Engineering, vol. 130, no. 4, pp. 349-359, 2004.

[12] USEPA, "Review of the D-CORMIX model," Science Advisory Board Report EPA-SAB-EC-99-011, USEPA, Washington, DC, USA, 1999, http://www.epa.gov/sciencel/ec99011.pdf.

[13] I. Alameddine and M. El-Fadel, "Brine discharge from desalination plants: a modeling approach to an optimized outfall design," Desalination, vol. 214, no. 1-3, pp. 241-260, 2007. 

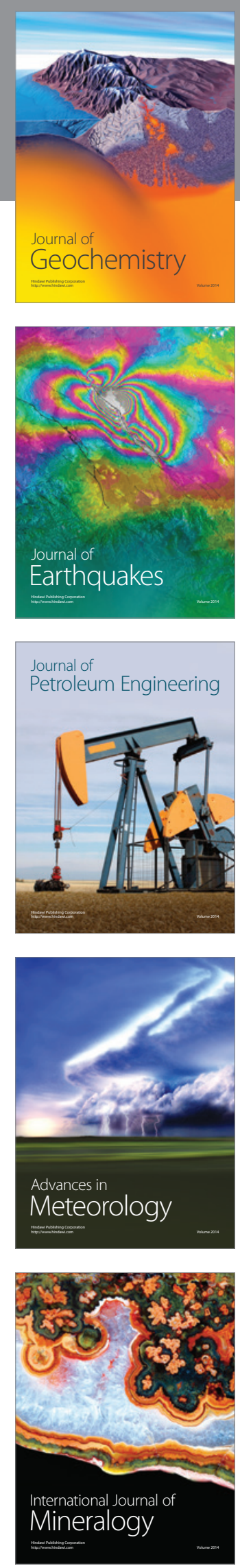
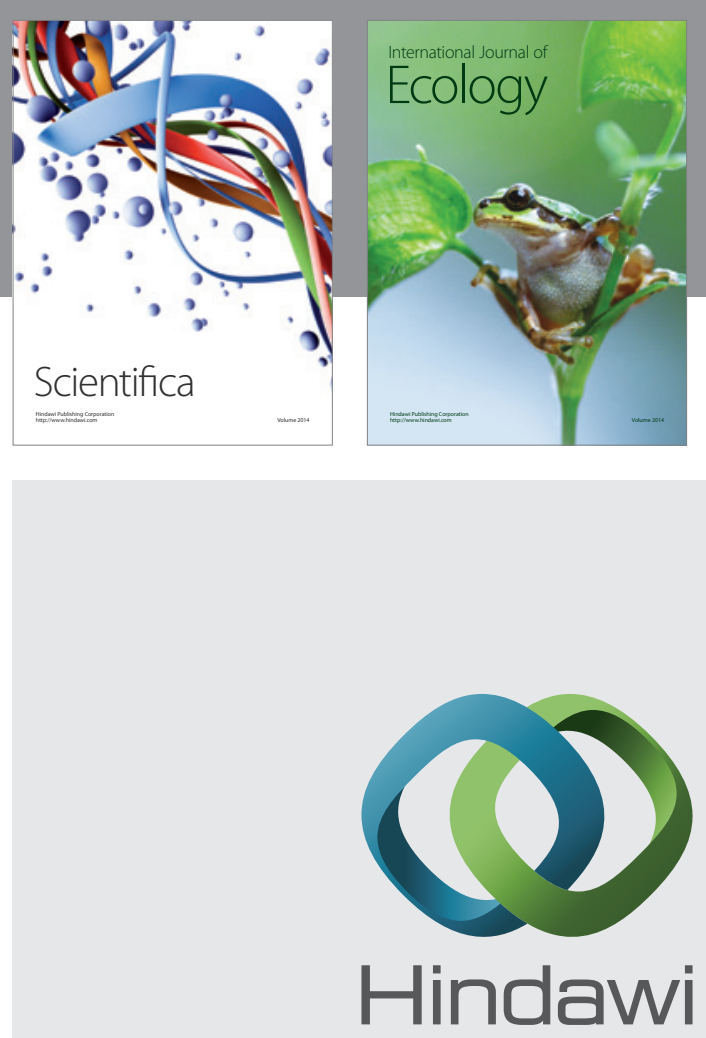

Submit your manuscripts at

http://www.hindawi.com
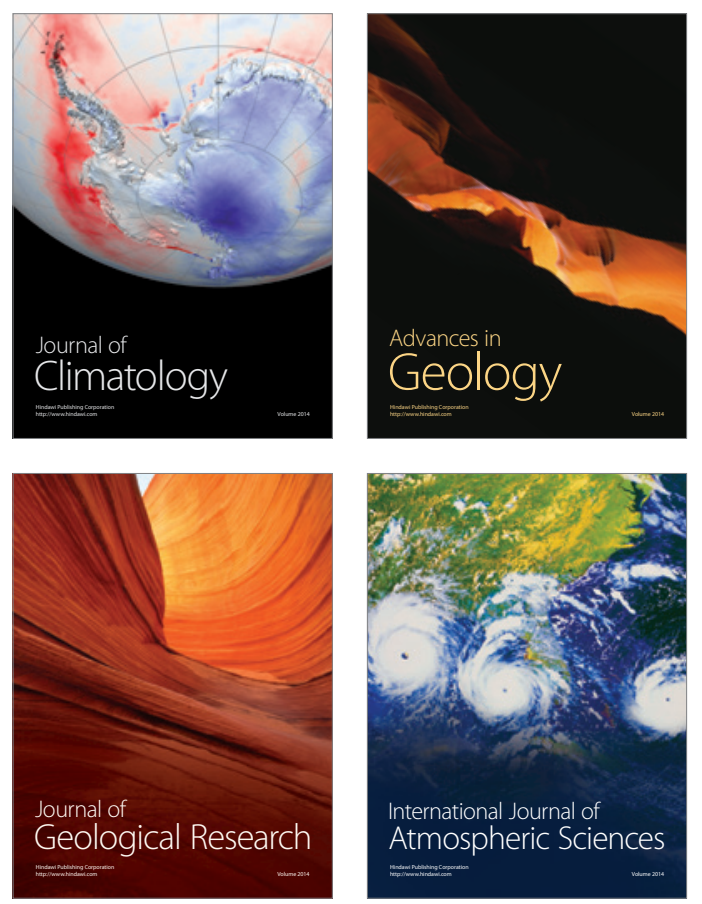

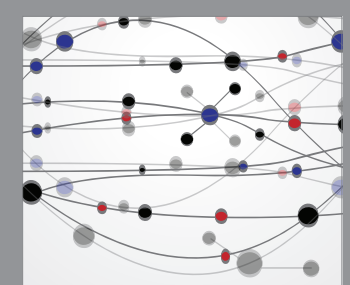

The Scientific

\section{World Journal}
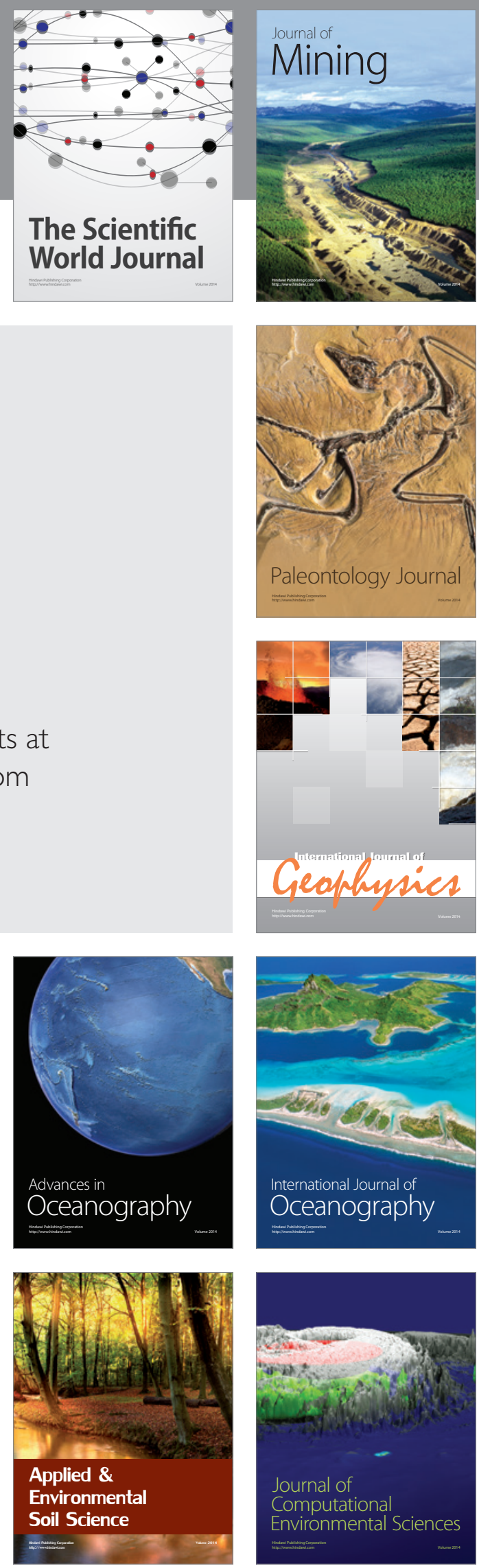